\title{
Human Flora-Associated (HFA) Animals for Studying the Role of Intestinal Flora in Human Carcinogenesis
}

\author{
Kazuhiro Hirayama* \\ Laboratory of Veterinary Public Health, Department of Veterinary Medical Science, Graduate School of Agricultural and Life Sciences, \\ The University of Tokyo, Bunkyo-ku, Tokyo 113-8657, Japan \\ Received for publication, July 3, 2002
}

\begin{abstract}
Although the intestinal flora is thought to have a critical role in carcinogenesis, there is little information regarding the role of the human intestinal flora on the effects of dietary and environmental mutagens in vivo. By inoculating germfree animals with feces, the major composition of human flora can be transferred into the ex-germfree animals, i.e. human flora-associated (HFA) animals. The HFA animals provide a stable tool for studying the ecosystem and metabolism of human intestinal flora, though they have some limitations as a model. The capacity of human feces to activate or inactivate mutagens could be transferred into HFA mice and the presence of an intestinal flora was essential for the activity of feces against the mutagens. DNA adduct formation after the administration of dietary and environmental mutagens to mice with different bacterial conditions, including HFA mice, were then analyzed as an in vivo biomarker of cancer risk, and the results indicate that the intestinal flora have an active role in DNA adduct formation. It has also been demonstrated that the role of human intestinal flora is different from that of experimental animals in vivo as well as the metabolic activities against mutagens in vitro. Studies using HFA animals should provide much needed information of relevance to humans regarding the role of intestinal flora in carcinogenesis in vivo. The HFA animals could then contribute to prevention strategies for cancer involving improvement of the intestinal flora.
\end{abstract}

Key words: HFA animals; intestinal flora; carcinogenesis; DNA adducts

\section{INTRODUCTION}

It is now relatively well established that diet is an important etiological factor in human carcinogenesis. For example, mutagenic/carcinogenic substances have been found in cooked food by using microbial mutation assays, and a series of heterocyclic amines has been isolated and identified as being among the most potent of these mutagens $(5,58)$. Mutagenic substances are also found in the environment; e.g., nitrate polycyclic hydrocarbons formed due to incomplete combustion of fossil fuels $(48,56)$. The concentrations of these substances might not be high enough to produce tumors by themselves, but humans are exposed continuously and to several carcinogenic agents simultaneously. Thus, the need to avoid exposure to carcinogens or, at least, to minimize exposure without greatly affecting daily life should be emphasized.

Epidemiological studies and risk estimates suggest that the intestinal flora increases the risk of cancer related to the diet (15) and environmental pollutants (33). A comparison between germfree (GF) and conventional

*Corresponding author. Mailing address: Laboratory of Veterinary Public Health, Department of Veterinary Medical Science, Graduate School of Agricultural and Life Sciences, The University of Tokyo, 1-1-1, Yayoi, Bunkyoku, Tokyo 113-8657, Japan. Phone: +81-3-5841-3094. Fax. +81-3-58418188. E-mail: akazu@mail.ecc.u-tokyo.ac.jp
(CV) animals also demonstrated that the intestinal flora plays an important role in the metabolism and the formation of mutagenic compounds $(2,4)$, and increases the formation of colon tumors $(39,40)$. On the other hand, it has been reported that intestinal bacteria can bind mutagenic compounds in vitro and the binding correlates well with the reduction in mutagenicity observed after exposure to the bacterial strains $(34,36)$.

\section{PRODUCTION OF HUMAN FLORA-ASSOCIATED (HFA) ANIMALS}

Although the intestinal flora is thought to have a critical role in carcinogenesis as mentioned above, most of the work in this field has been performed using rodent models and there is little information in literature regarding the role of human intestinal flora on the effects of dietary and environmental mutagens in vivo. This is largely due to the difficulties of studying the effects of human intestinal flora; e.g., difficulties of controlling the environmental and dietary conditions of humans. There are also ethical problems associated with studies on the effects of carcinogenic or toxic substances using human volunteers. In addition, it must be kept in mind that the composition and metabolic activities of intestinal flora of experimental animals are significantly different from those of humans (23), making extrapolation of results from animal studies to the human sys- 
tem questionable.

To find a solution to this problem, GF animals associated with human fecal flora (i.e., human flora-associated (HFA) animals) have been considered as a tool for studying the ecology and metabolism of the intestinal bacteria of humans (21). By inoculating feces from various species of animals and humans, the fecal bacteria of the donor animals can be transferred to GF animals $(7,10,18,30,38)$. Hirayama et al. $(23,24)$ inoculated GF mice with a fecal suspension of healthy human adults and the major composition of human flora could be transferred into HFA mice. Interestingly, bifidobacteria were eliminated from some of the HFA mouse groups while other dominant bacterial groups remained constant. The elimination of bifidobacteria seemed to be dependent on the composition of the flora in the inoculated sample (23).

\section{MAINTENANCE OF INTESTINAL FLORA OF HFA MICE}

The human intestinal flora established in the intestine of HFA mice can be reproduced in the intestine of the offspring of the HFA mice without any remarkable change in composition $(23,26)$. Most of the intestinal bacteria of mother HFA mice colonized in the intestines of the offspring within 3 weeks after birth and the compositions of the flora of offspring were similar to those of their mothers. However, the development of intestinal flora in the offspring of HFA mice is similar to that of CV mice, but not to that of human infants. In human infants, bifidobacteria become the most predominant bacteria within 1 week after birth $(3,32)$, but bifidobacteria never became the most predominant bacteria in the infant HFA mice, even though the mother HFA mice harbored a large population of bifidobacteria (26).

The intestinal flora of HFA mice was also reproduced by cage-mating. When GF mice were cage-mated with HFA mice, the composition of intestinal flora of the ex-GF mice became similar to that of HFA mice by 8 days after contact with HFA mice, and this balance was maintained thereafter (25). These studies indicate that the intestinal flora, once established in HFA mice, can be maintained for a long period.

\section{METABOLIC ACTIVITIES OF INTESTINAL FLORA OF HFA MICE}

It has been demonstrated that certain enzymic activities of human fecal flora can be simulated in rats associated with human intestinal bacteria (31). Hirayama et al. (23) reported that the activities of some enzyme activities of intestinal flora in HFA mice were similar to those in humans and different from those in $\mathrm{CV}$ mice, while others were not. The activities of the fecal enzymes of HFA mice were reproduced in their offspring (23).

The concentrations of putrefactive products in the feces of HFA mice were much lower than those in human feces and similar to those in CV mice, while $p$ cresol, which is detected in human feces but not in $\mathrm{CV}$ mice, was detected in most of the HFA mouse groups and the concentration of fecal indole in some of the HFA mouse groups was significantly higher than that in CV mice (23). Although the concentration of fecal short-chain fatty acids (SCFAs) in HFA mice was significantly lower than that in humans and similar to that in CV mice, the composition of SCFAs in HFA mice was closer to that in humans than that in $\mathrm{CV}$ mice (23).

Thus, bacterial metabolism in the intestines of HFA mice reflected that of human feces with respect to some metabolic activities but not others, even though the bacterial composition of the feces of HFA mice was similar to that of the inocula.

\section{APPLICATION OF HFA ANIMALS TO STUDIES ON THE INTESTINAL FLORA OF HUMANS}

HFA animals have often been used to investigate the effects of dietary components, including oligosaccharides, on the ecology $(29,44,57)$ and fermentation $(8$, $28,29,41$ ) of human intestinal flora. The effects of diet and intestinal flora on morphological and physiological properties of the host have also been investigated using HFA animals (49-51). HFA animals have been used in nutritional studies as well $(12,16)$.

The influences of different dietary components on the composition of human intestinal flora may be detected more clearly in HFA mice than in humans. For example, Hirayama et al. (25) employed HFA mice to investigate the effects of high-meat and high-bran diet on intestinal flora and clearly detected changes in the composition of the flora.

HFA mice may be a useful tool for studies which are impossible or difficult to investigate using human volunteers. HFA animals have been used to study colonization resistance of the intestinal flora to pathogenic bacteria $(11,19,20)$. HFA mice have also been used to evaluate the effects of residual and therapeutic doses of antibiotics on human intestinal flora $(1,14,37,55)$. Recently, immunological studies have employed HFA mice as an experimental tool $(46,53)$. 


\section{APPLICATION OF HFA ANIMALS TO CANCER-RELATED STUDIES}

Some of the enzyme activities of intestinal flora, including $\beta$-glucuronidase, are thought to be related to human cancer. The production of putrefactive products by intestinal flora is also thought to play a role in carcinogenesis. The effects of dietary components on the activities of these cancer-related enzymes and the production of the putrefactive products have been investigated using HFA animals $(13,17,28,44,52)$. The potentially beneficial effects of probiotics to human health in this respect have also been suggested in studies using HFA animals (9). Narushima et al. (35) investigated the metabolic activity of human intestinal bacteria in the conversion of primary bile acids to secondary bile acids, which have been implicated in human carcinogenesis, using HFA mice and gnotobiotic techniques.

HFA animals have also been employed to investigate the generation of mutagenic or carcinogenic compounds by human intestinal flora. Rumney et al. (45) investigated the metabolism of dietary mutagen, 2amino-3-methyl-3H-imidazo[4,5-f]quinoline (IQ), to a 7-keto derivative by intestinal flora and demonstrated that the use of HFA rats makes the results of particular relevance to humans, especially when the animals were fed human diets. Unlike IQ, the metabolite is a directacting mutagen in the Salmonella mutagenicity test. The conversion of IQ was enhanced in HFA rats fed a highrisk diet for colon cancer (17) and decreased by the ingestion of an indigestible sugar (44). Ward et al. (59) compared the effect of dietary fat on the production of carcinogenic $N$-nitrosoamines between rats harboring different intestinal flora, including HFA rats.

Roland et al. (42) investigated the effects of dietary fiber on hepatic and intestinal toxication and detoxification enzyme activities in rats inoculated with human whole fecal flora.

\section{HFA ANIMALS AS A TOOL FOR STUDYING HUMAN CARCINOGENESIS IN VIVO}

HFA animals have been used as a new kind of model to investigate the role of human intestinal flora in the effects of mutagenic/carcinogenic substances on the host in vivo. Hirayama et al. (22) investigated the possible role of human intestinal flora in carcinogenesis in vivo by exploiting HFA mice. They inoculated GF mice with human fecal suspensions to generate HFA mice and the capacity of human feces to increase or decrease mutagenic activities of chemicals tested could be transferred into the HFA mice. In comparing GF and HFA mice, the presence of intestinal flora was essential for the activity of feces against the mutagens. GF mice, HFA mice and mice with mouse flora were then administered dietary and environmental mutagens orally. DNA adduct formation was used as an in vivo biomarker of cancer risk. The process of chemical carcinogenesis is thought to be initiated by the covalent binding of genotoxic agents to DNA, and the measurement of levels of this binding, DNA adduct, may be useful as a biomarker for early detection of cancer risk (6). The results showed that the presence of intestinal flora enhances DNA adduct formation by IQ and 2-nitrofluorene, and in contrast to IQ and 2-nitrofluorene, there were more DNA adducts after 2-amino- $\alpha$-carboline treatment in some tissues, including colon, in GF mice than in mice with bacteria. It was also demonstrated in this study that human intestinal flora has a different effect than mouse flora on DNA adduct formation in vivo as well as in vitro metabolic activities against mutagens.

Scheepers et al. (47) administered 2-aminofluorene and 2-nitrofluorene to GF rats, HFA rats and rats with rat flora, and also indicated that the metabolic activity of intestinal flora is an essential step in haemoglobin and DNA adduct formation. Kassie et al. (27) showed the strong impact of intestinal flora on the genotoxic effects of IQ using HFA rats and single-cell gel electrophoresis (Comet assay). Rowland et al. (43) also exploited HFA animals to investigate the protective effects of lactulose consumption from genotoxic effects of carcinogen in Comet assay. Tache et al. (54) demonstrated the difference between human and rat intestinal flora in the colon tumor enhancement effect of carrageenans by scoring aberrant crypt foci.

\section{CONCLUSIONS}

Although intestinal flora has a critical role in carcinogenesis, little is known about the role of human intestinal flora in vivo. In addition, it has been demonstrated that the role of human intestinal flora in carcinogenesis is different from that of experimental animals in vivo, as well as in relation to metabolic activities against mutagens/carcinogens in vitro. HFA animals provide a stable tool for studying the ecosystem and metabolism of human intestinal flora in conditions similar to those found in humans, though they have some limitations as a model. Studies using HFA animals should provide much needed information of relevance to humans regarding the role of intestinal flora on carcinogenesis in vivo. The use of HFA animals could then contribute to prevention strategies for cancer involving improvement of the intestinal microbial 
balance by modulation of dietary habits or ingestion of probiotics.

\section{REFERENCES}

(1) Andremont A, Raiboud P, Tancrède C. 1983. Effect of erythromycin on microbial antagonisms: A study in gnotobiotic mice associated with a human faecal flora. J Infect Dis 148: 579-587.

(2) Ball LM, Rafter JJ, Gustafsson J-Å, Gustafsson B-E, Kohan MJ, Lewtas J. 1991. Formation of mutagenic urinary metabolites from 1-nitropyrene in germ-free and conventional rats: role of the gut flora. Carcinogenesis 12: 1-5.

(3) Benno Y, Mitsuoka T. 1986. Development of intestinal microflora in human and animals. Bifidobacteria Microflora 5: 13-25.

(4) Chadwick RW, George SE, Claxton LD. 1992. Role of the gastrointestinal mucosa and microflora in the bioactivation of dietary and environmental mutagens or carcinogens. Drug Metab Rev 24: 425-492.

(5) Commoner B, Vithayathil A, Dolara P, Nair S, Madyastha P, Cuca G. 1978. Formation of mutagen in beef and beef extract during cooking. Science 201: 913-916.

(6) Cui X-S, Torndal U-B, Eriksson LC, Möller L. 1995. Early formation of DNA adducts compared with tumor formation in a long-term tumor study in rats after administration of 2-nitrofluorene. Carcinogenesis 16: 2135-2141.

(7) Debure A, Colombel JF, Flourie B, Rautureau M, Rambaud JC. 1989. Comparison of the implantation and metabolic activity of human and rat fecal flora administered to axenic rats. Gastroenterol Clin Biol 13: 25-31.

(8) Djouzi Z, Andrieux C. 1997. Compared effects of three oligosaccharides on metabolism of intestinal microflora in rats inoculated with a human faecal flora. $\mathrm{Br} \mathbf{J}$ Nutr $\mathbf{7 8}$ : 313-324.

(9) Djouzi Z, Andrieux C, Degivry M-C, Bouley C, Szylit O. 1997. The association of yogurt starters with Lactobacillus casei DN 114.001 in fermented milk alters the composition and metabolism of intestinal microflora in germ-free rats and in human flora-associated rats. J Nutr 127: 2260 2266.

(10) Ducluzeau R, Ladiré M, Raibaud P. 1984. Effect of bran ingestion on the microbial faecal floras of human donors and of recipient gnotobiotic mice, and on the barrier effects exerted by these floras against various potentially pathogenic microbial strains. Ann Microbiol 135A: 303318.

(11) Ducluzeau R, Rapine C, Courvalin C, Raibaud P. 1978. Transfer of the fecal microbial flora from holoxenic piglets and adult pigs to axenic piglets and axenic adult mice: effect of the animal host and of the diet on the fecal microbial pattern of these animals. Ann Microbiol 129B: 597612.

(12) Dufour-Lescoat C, Le Coz Y, Szylit O. 1991. Nutritional effects of wheat bran and beet fiber in germ-free rats and in heteroxenic rats inoculated with human flora. Sci Aliment 11: 397-408.

(13) Fujiwara S, Hirota T, Nakazato H, Mizutani T, Mitsuoka
T. 1991. Effect of konjac mannan on intestinal microbial metabolism in mice bearing human flora and in conventional F344 rats. Food Chem Toxicol 29: 601-606.

(14) Gismondo MR, Drago L, Lombardi A, Fassina C, Cesana M. 1995. Impact of rufloxacin and ciprofloxacin on the intestinal microflora in a germ-free mice model. Chemotherapy 41: 281-288.

(15) Gorbach SL, Goldin BR. 1990. The intestinal microflora and the colon cancer connection. Rev Infect Dis 12: S252S261.

(16) Grolier P, Borel P, Duszka C, Lory S, Alexandre-Gouabau MC, Azais-Braesco V, Nugon-Baudon L. 1998. The bioavailability of $\alpha$-and $\beta$-carotene is affected by gut microflora in the rat. Br J Nutr 80: 199-204.

(17) Hambly RJ, Rumney CJ, Fletcher JME, Rijken PJ, Rowland IR. 1997. Effects of high- and low-risk diets on gut microflora-associated biomarkers of colon cancer in human flora-associated rats. Nutr Cancer 27: 250-255.

(18) Hazenberg MP, Bakker M, Verschoor-Burggraaf A. 1981. Effects of the human intestinal flora on germ-free mice. J Appl Bacteriol 50: 95-106.

(19) Hentges DJ, Marsh WW, Petschow BW, Rahman ME, Dougherty SH. 1995. Influence of a human milk diet on colonization resistance mechanisms against Salmonella typhimurium in human faecal bacteria-associated mice. Microbial Ecol Health Dis 8: 139-149.

(20) Hentges DJ, Marsh WW, Petschow BW, Thal WR, Carter MK. 1992. Influence of infant diets on the ecology of the intestinal tract of human flora-associated mice. J Pediatr Gastroenterol Nutr 14: 146-152.

(21) Hirayama K. 1999. Ex-germfree mice harboring intestinal microbiota derived from other animal species as an experimental model for ecology and metabolism of intestinal bacteria. Exp Anim 48: 219-227.

(22) Hirayama K, Baranczewski P, Åkerlund J-E, Midtvedt T, Möller L, Rafter J. 2000. Effects of human intestinal flora on mutagenicity of and DNA adduct formation from food and environmental mutagens. Carcinogenesis 21: $2105-$ 2111.

(23) Hirayama K, Itoh K, Takahashi E, Mitsuoka T. 1995. Comparison of composition of faecal microbiota and metabolism of faecal bacteria among 'human-flora-associated' mice inoculated with faeces from six different human donors. Microbial Ecol Health Dis 8: 199-211.

(24) Hirayama K, Kawamura S, Mitsuoka T. 1991. Development and stability of human faecal flora in the intestine of ex-germ-free mice. Microbial Ecol Health Dis 4: 95-99.

(25) Hirayama K, Mishima M, Kawamura S, Itoh K, Takahashi E, Mitsuoka T. 1994. Effects of dietary supplements on the composition of fecal flora of human-flora-associated (HFA) mice. Bifidobacteria Microflora 13: 1-7.

(26) Hirayama K, Miyaji K, Kawamura S, Itoh K, Takahashi E, Mitsuoka T. 1995. Development of intestinal flora of human-flora-associated (HFA) mice in the intestine of their offspring. Exp Anim 44: 219-222.

(27) Kassie F, Rabot S, Kundi M, Chabicovsky M, Qin H-M, Knasmüller S. 2001. Intestinal microflora plays a crucial role in the genotoxicity of the cooked food mutagens 2 - 
amino-3-methylimidazo[4,5-f]quinoline (IQ). Carcinogenesis 22: 1721-1725.

(28) Kikuchi H, Andrieux C, Riottot M, Bensaada M, Popot F, Beaumatin P, Szylit O. 1996. Effect of two levels of transgalactosylated oligosaccharide intake in rats associated with human faecal microflora on bacterial glycolytic activity, end-products of fermentation and bacterial steroid transformation. J Appl Bacteriol 80: 439-446.

(29) Kleessen B, Hartmann L, Blaut M. 2001. Oligofructose and long-chain inulin: influence on the gut microbial ecology of rats associated with a human faecal flora. Br J Nutr 86: 291-300.

(30) Maejima K, Sasaki J, Shimoda K, Kurosawa T. 1981. Bacterial flora of ex-germfree mice after oral inoculation of feces from various species of conventional animals. Exp Anim 30: 157-160.

(31) Mallett AK, Bearne CA, Rowland IR, Farthing MJG, Cole CB, Fuller R. 1987. The use of rats associated with a human faecal flora as a model for studying the effects of diet on the human gut microflora. J Appl Bacteriol 63: 39-45.

(32) Mitsuoka T, Hayakawa K. 1972. Die Darmflora bei Menschen. I. Mitteilung. Die Zusammensetzung der Faekalflora der verschiedenen Altergruppen. Zbl Bakteriol Parasitenkd Infektionskr Hyg I Orig A 233: 333-352.

(33) Möller L, Torndal UB, Eriksson LC, Gustafsson J-Å. 1989. The air pollutant 2-nitrofluorene as initiator and promoter in a liver model for chemical carcinogenesis. Carcinogenesis 10: 435-440.

(34) Morotomi M, Mutai M. 1986. In vitro binding of potent mutagenic pyrolyzates to intestinal bacteria. J Natl Cancer Inst 77: 195-201.

(35) Narushima S, Itoh K, Kuruma K, Uchida K. 2000. Composition of cecal bile acids in ex-germfree mice inoculated with human intestinal bacteria. Lipids 35: 639-644.

(36) Orrhage K, Sillerström E, Gustafsson J-Å, Nord CE, Rafter J. 1994. Binding of mutagenic heterocyclic amines by intestinal and lactic acid bacteria. Mutat Res 311: 239-248.

(37) Perrin-Guyomard A, Cottin S, Corpet DE, Boisseau J, Poul JM. 2001. Evaluation of residual and therapeutic doses of tetracycline in the human-flora-associated (HFA) mice model. Reg Toxicol Pharmacol 34: 125-136.

(38) Raibaud P, Ducluzeau R, Dubos F, Hudault S, Bewa H, Muller MC. 1980. Implantation of bacteria from the digestive tract of man and various animals into gnotobiotic mice. Am J Clin Nutr 33: 2440-2447.

(39) Reddy BS, Narisawa T, Wright P, Vukusich D, Weisburger JH, Wynder EL. 1975. Colon carcinogenesis with azoxymethane and dimethylhydrazine in germ-free rats. Cancer Res 35: 287-290.

(40) Reddy BS, Weisburger JH, Narisawa T, Wynder EL. 1974. Colon carcinogenesis in germ-free rats with 1,2-dimethylhydrazine and $N$-methyl- $N$-nitro- $N$-nitrosoguanidine. Cancer Res 34: 2368-2372.

(41) Roland N, Nugon-Baudon L, Andrieux C, Szylit O. 1995. Comparative study of the fermentative characteristics of inulin and different types of fibre in rats inoculated with a human whole faecal flora. Br J Nutr 74: 239-249.

(42) Roland N, Nugon-Baudon L, Flinois JP, Beaune P. 1994.
Hepatic and intestinal cytochrome P-450, glutathione-Stransferase and UDP-glucuronosyl transferase are affected by six types of dietary fiber in rats inoculated with human whole fecal flora. J Nutr 124: 1581-1587.

(43) Rowland IR, Bearne CA, Fischer R, Pool-Zobel BL. 1996. The effect of lactulose on DNA damage induced by DMH in the colon of human flora-associated rats. Nutr Cancer 26: $37-47$.

(44) Rowland IR, Tanaka R. 1993. The effects of transgalactosylated oligosaccharides on gut flora metabolism in rats associated with a human faecal microflora. J Appl Bacteriol 74: 667-674.

(45) Rumney CJ, Rowland IR, O'Neill IK. 1993. Conversion of IQ to 7-OHIQ by gut microflora. Nutr Cancer 19: 67-76.

(46) Sandre C, Gleizes A, Forestier F, Gorges-Kergot R, Chilmonczyk S, Leonil J, Moreau MC, Labarre C. 2001. A peptide derived from bovine $\beta$-casein modulates functional properties of bone marrow-derived macrophages from germfree and human flora-associated mice. J Nutr 131: 2936-2942.

(47) Scheepers PTJ, Velders DD, Steenwinkel MJST, van Delft JHM, Driessen W, Strätemans MME, Baan RA, Koopman JP, Noordhöck J, Bos RP. 1994. Role of the intestinal microflora in the formation of DNA and haemoglobin adducts in rats treated with 2-nitrofluorene and 2-aminofluorene by gavage. Carcinogenesis 15: 1433-1441.

(48) Schützle D, Riley TL, Prater TJ, Harvey TM, Hunt DF. 1982. Analysis of nitrated polycyclic aromatic hydrocarbons in diesel particulates. Anal Chem 54: 265-271.

(49) Sharma R, Schumacher U. 1995. Morphometric analysis of intestinal mucins under different dietary conditions and gut flora in rats. Dig Dis Sci 40: 2532-2539.

(50) Sharma R, Schumacher U. 1995. The influence of diets and gut microflora on lectin binding patterns of intestinal mucins in rats. Lab Invest 73: 558-564.

(51) Sharma R, Schumacher U. 1996. The diet and gut microflora influence the distribution of enteroendocrine cells in the rat intestine. Experientia 52: 664-670.

(52) Silvi S, Rumney CJ, Cresci A, Rowland IR. 1999. Resident starch modifies gut microflora and microbial metabolism in human flora-associated rats inoculated with faeces from Italian and UK donors. J Appl Microbiol 86: 521530.

(53) Sudo N, Aiba Y, Takaki A, Tanaka K, Yu XN, Oyama N, Koga Y, Kubo C. 2000. Dietary nucleic acids promote a shift in Th1/Th2 balance toward Th1-dominant immunity. Clin Exp Allergy 30: 979-987.

(54) Tache S, Peiffer G, Millet AS, Corpet DE. 2000. Carrageenan gel and aberrant crypt foci in the colon of conventional and human flora-associated rats. Nutr Cancer 37: 193 198.

(55) Tancrède C, Andremont A, Kherbiche AM. 1981. Germfree mice associated with human flora as a means of bacteriological surveillance of neutropenic patients in sterile environments. In Recent Advances in Germfree Research, Sasaki S, Ozawa A, Hashimoto K (eds), Tokai University Press, Tokyo, p. 755-758.

(56) Tokiwa H, Nakagawa R, Horikawa K. 1985. Mutagenic/ 
carcinogenic agents in indoor pollutants: the dinitropyrenes generated by kerosene heaters and fuel gas and liquefied petroleum gas burners. Mutat Res 157: 39-47.

(57) Veenendaal D, de Boer J, Meijer BC, van der Waaij D, Wilkinson MH. 1996. Micromorphometrical analysis of rodent related (SPF) and unrelated (human) gut microbial flora in germfree mice by digital image processing. Epidemiol Infect 116: 35-40.
(58) Wakabayashi K, Nagao M, Esumi H, Sugimura T. 1992. Food-derived mutagens and carcinogens. Cancer Res 52: 2092s-2098s.

(59) Ward FW, Coates ME, Cole CB, Fuller R. 1990. Effect of dietary fats on endogenous formation of $N$-nitrosamines from nitrate in germ-free and conventional rats and rats harbouring a human flora. Food Add Contam 7: 597-604. 